\title{
KORELASI IgM SALMONELLA DENGAN SGOT PADA PASIEN SUSPEK DEMAM TYPHOID DI RUMAH SAKIT BAPTIS KEDIRI
}

\author{
The Correlation Igm Salmonella Result With SGOT In Typhoid Fever Suspect Patients \\ in Baptis Hospital Kediri
}

\author{
Lidya Natalia H. Sarira ${ }^{1}$, Jessi Suryani Setiawan ${ }^{2}$ \\ ${ }^{1}$ Sekolah Pascasarjana, Program Studi Imunologi Universitas Airlangga, Surabaya \\ ${ }^{2}$ D4 Teknologi Laboratorium Medis Institut Ilmu Kesehatan Bhakti Wiyata Kediri
}

Koresponden: lidya.sarira01@gmail.com/082330412294

\begin{abstract}
Typhoid fever was an acute systemic infectious disease which was caused by Salmonella typhi germ. This disease was an endemic disease and it was still health problem in the developing countries like Indonesia. Typhoid fever diagnose was made based on the sympthon and supporting examination, such as Rapid Test and SGOT. The research purposed to know the examination result correlation of IgM Salmonella Rapid Test with SGOT level to typhoid fever suspect patients in Baptis Hospital Kediri. In this research used the type of laboratorium research correlation study. The research was done by observing the relation of one sympthon with other sympthon, or one variable with other variable. Variable was measured was the examination of IgM Salmonella and SGOT level, and also the examination result which was gotten. Based on data analysis Coefficient Biserial test was gotten $r=0.201$, so $H_{1}$ was accepted, showed that there was the examination result correlation on IgM Salmonella Rapid Test with SGOT level to the Typhoid Fever Suspect Patients.
\end{abstract}

Keywords: IgM Salmonella, SGOT, Typhoid Fever Suspect Patient

\begin{abstract}
ABSTRAK
Demam typhoid adalah suatu penyakit infeksi sistemik bersifat akut yang disebabkan oleh kuman Salmonella typhi. Penyakit ini merupakan penyakit endemik dan masih merupakan masalah kesehatan di negara berkembang seperti Indonesia. Diagnosa demam typhoid ditegakkan berdasarkan gejala dan pemeriksaan penunjang, diantaranya Rapid Test dan SGOT. Penelitian ini bertujuan untuk mengetahui korelasi hasil pemeriksaan IgM Salmonella Rapid Test dengan kadar SGOT pada pasien suspek demam typhoid di Rumah Sakit Baptis Kediri. Pada penelitian ini menggunakan jenis penelitian laboratorium studi korelasi (correlation study). Penelitian ini dilakukan dengan cara melihat hubungan antara gejala satu dengan gejala lain, atau variabel satu dengan variabel lainnya. Variabel yang diukur adalah pemeriksaan IgM Salmonella dan kadar SGOT, serta hasil pemeriksaan yang didapatkan. Berdasarkan analisa data uji Koefisien Biserial didapatkan $\mathrm{r}=0.201$, maka $\mathrm{H}_{1}$ diterima, menunjukan bahwa ada korelasi hasil pemeriksaan IgM Salmonella Rapid Test dengan kadar SGOT pada pasien suspek demam typhoid.
\end{abstract}

Kata kunci: IgM Salmonella, SGOT, Pasien Suspek Demam Typhoid. 


\section{PENDAHULUAN}

Demam typhoid adalah suatu penyakit infeksi sistemik bersifat akut yang disebabkan oleh kuman Salmonella typhi. Penyakit ini ditandai dengan demam berkepanjangan, malaise, obstipasi atau diare, perasaan tidak enak diperut, dan splenomegali (pembesaran limpa) (Widodo, 2006).

Demam typhoid masih merupakan penyakit endemik di Indonesia. Penyakit ini termasuk penyakit menular yang tercantum dalam undang-undang nomor 6 tahun 1962 tentang wabah. Kelompok penyakit menular ini merupakan penyakit yang mudah menular dan dapat menyerang banyak orang sehingga dapat menimbulkan wabah (Widodo, 2009).

Demam typhoid tersebar merata diseluruh dunia. Insiden penyakit Typhoid di dunia menurut WHO mencapai 11-20 juta kasus pertahun dan menyebabkan 128.000 sampai 161.000 kematian tiap tahunnya (WHO, 2018).

Berdasarkan data dari profil kesehatan Indonesia tahun 2010 yang dikeluarkan oleh Kementerian Kesehatan Republik Indonesia (2011), demam typhoid menempati urutan ke-3 dari 10 pola penyakit terbanyak pasien rawat inap di Rumah Sakit sebesar 0,67\% dengan kasus sebagai berikut, laki-laki: 19.706, perempuan: 21.375, proporsi kasus laki-laki: 47,97\%, perempuan: $52,03 \%$, jumlah pasien keluar: 41.081, dan meninggal: 274 (Kementerian Kesehatan Republik Indonesia, 2011).

Insiden di Rumah Sakit Baptis sendiri di tahun 2014 berjumlah 361pasien, dengan angka kejadian perbulannya sebagai berikut: Januari: 42pasien, Februari: 44pasien, Maret:38 pasien, April: 22 pasein, Mei: 31pasien, Juni: 21 pasien, Juli: 15pasien, Agustus: 22 pasien, September: 40pasien, Oktober: 28pasien, November: 26 pasien, Desember: 32pasien.
Sampai saat ini, demam typhoid masih merupakan masalah kesehatan, hal ini disebabkan oleh kesehatan lingkungan yang kurang memadai, penyediaan air minum yang tidak memenuhi syarat, serta tingkat sosial ekonomi dan tingkat pendidikan masyarakat yang kurang. Walaupun pengobatan demam typhoid tidak terlalu menjadi masalah, namun diagnosis kadang-kadang menjadi masalah, terutama di tempatyang tidak dapat dilakukan pemeriksaan kuman maupun pemeriksaan laboratorium penunjang. Mengingat hal tersebut, pengenalan gejala klinis menjadi sangat penting untuk membantu diagnosis.

Penelitian terkait oleh Pohan HT (2004) dengan judul Maninfestasi Klinis dan Laboratorium Demam Typhoid di RS Persahabatan Jakarta menyatakan bahwa penderita tersangka demam typhoid dapat terjadi peningkatan kadar SGOT (Serum Glutamic Oxaloacetic Transaminase) dan kadar SGPT (Serum Glutamic Pyruvic Transaminase). Peningkatan kadar SGOT dan SGPT dapat menyebabkan terjadinya komplikasi pada hati misalkan hepatitis typhoid.

SGOT dan SGPT seringkali meningkat tetapi kembali normal setelah sembuhnya demam typhoid. Penelitian ini bertujuan untuk mengetahui korelasi hasil pemeriksaan IgM Salmonella Rapid test dengan kadar SGOT pada pasien suspek demam typhoid di Rumah Sakit Baptis Kediri.

\section{METODE}

\section{Jenis Penelitian, Waktu dan Tempat Penelitian}

Pada penelitian ini menggunakan jenis penelitian laboratorium studi kolerasi (correlation study). Penelitian ini dilaksanakan tanggal 11 Mei-11 Juni 2015. Penelitian ini dilaksanakan di 
Laboratorium Rumah Sakit Baptis Kediri.

\section{Populasi dan Sampel}

Populasi pada penelitian ini adalah pasien suspek demam typhoid di Rumah Sakit Baptis Kediri. Sampel dalam penelitian ini adalah 33 orang pasiens suspek demam typhoid di Rumah Sakit Baptis Kediri.

\section{Teknik Pengumpulan Data}

1. Dalam penelitian ini digunakan data primer, yaitu data yang secara langsung diambil dari objek penelitian oleh peneliti.Data yang diperoleh digunakan untuk mengetahui korelasi hasil pemeriksaan IgM Salmonella Rapid Test dengan kadar SGOT pada pasien suspek demam typhoid.

2. Pemeriksaan IgM Salmonella metode Rapid test

Alat yang digunakan dalam penelitian ini adalah: rapid test, pipet tetes plastik, dan timer.

Prosedur kerja: pertama-tama gunakan pipet tetes plastik untuk memindahkan 1 tetes sampel kedalamc ard test kemudian ditambahkan 2 tetes sampel diluent dalam sumuran sampel, selanjutnya hasil dapat dibaca setelah 15 menit (KIT Typhoid IgG/IgM Rapid test, 2015).

Interpretasi Hasil: positif jika munculnya garis merah pada control dan test (T2), negatif jika hanya muncul garis merah pada control dan tidak muncul garis merah pada test (T1 dan T2), dan invalid jika tidak muncul garis merah pada control dan test.

\section{Pemeriksaan SGOT}

Alat yang digunakan dalam penelitian ini: sample cup, yellow tip, clinipet $200 \mu 1$ dan auto analyzer TMS 1024i.

Prosedur Kerja: Dilakukan pengambilan darah vena pada pasien suspek demam typhoid. Kemudian darah vena dicentrifuge, dan dipipet serumnya sebanyak 200 $\mu 1$, masukan kedalam sampel cup. Kemudian di lakukan langkah sebagai berikut :Klik "order" pada monitor, klik "patient" Masukan identitas pasien sesuai dengan yang tertera pada joblist, klik "upload"Kemudian klik "exit"Pilih parameter pemeriksaan yang diminta, klik "order", lalu klik "exit"Cup sampel yang berisi serum di letakkan pada tempat sampel yang sesuai dengan nomor sampel pada monitorKlik "start", print hasiInya.

\section{Pengolahan dan analisis Data}

Pengolahan data dalam penelitian ini dilakukan dengan menggunakan bantuan komputer yaitu dengan menggunakan uji Koefisien Biserial. Langkah-langkah analisis data yang digunakan dalam penelitian ini antara lain: editing, coding, entery data, dan tabulasi

\section{HASIL}

Dalam penelitian ini, penentuan kriteria sampel sangat dibutuhkan untuk menentukan layak atau tidaknya sampel tersebut untuk digunakan. Kriteria sampel terdirid ari 2 macam yaitu kriteria Inklusi dan Eksklusi. Kriteria Inklusi meliputi pasien suspek demam typhoid dan kriteria eksklusi terdiri meliputi sampel hemolisis atau lipemik.

Dari 33 sampel pemeriksaan Rapid Test sebagian besar didapatkan hasil positif yaitu sebesar 28 sampel (87\%) dan 5 sampel (13\%) memberikan hasil negatif.Gambar 1 (Histogram kadar SGOT) dapat diketahui kadar SGOT rata-rata dari 33 responden adalah 102,79 U/L.Berdasarkan analisa data uji Koefisien Biserial didapatkan $r=0.201$, maka $\mathrm{H}_{1}$ diterima, menunjukan bahwa ada korelasi hasil pemeriksaan IgM Salmonella Rapid Test dengan kadar SGOT pada pasien suspek demam typhoid.

Tabel 1. Hasil pemeriksaan IgM Salmonella Rapid test dengan kadar SGOT terhadap 33 sampel serum pasien 
suspek demam typhoid di Rumah Sakit Baptis Kediri. Tabel 2 menunjukan karakteristik subjekpenelitian, dapat diketahui responden penelitian rata-rata 22.9 tahun dan usia responden yang paling muda adalah 5 tahun. Tabel 3 menunjukan karakteristik subjek penelitian berdasarkan jenis kelamin, dapat diketahui bahwa sebagian besar responden penelitian adalah laki-laki sebanyak 17 orang $(52 \%)$ dan 16 orang (48\%) adalah perempuan dari total keseluruhan 33 responden. Tabel 4 merupakan hasil pemeriksaan Rapid Test, dapat diketahui bahwa dari 33 sampel pemeriksaan Rapid Test sebagian besar didapatkan hasil positif yaitu sebanyak 28 sampel (87\%) dan 5 sampel $(13 \%)$ memberikan hasil negatif.

\section{PEMBAHASAN}

Rapid test Salmonella typhi IgG/IgM merupakan test strip menggunakan metode immunochromatographic dan merupakan uji cepat kualitatif untuk mendeteksi diferensial antibodi $\mathrm{IgG}$ dan IgM Salmonella typhi dalam serum manusia, plasma atau whole blood (Salmonella typhi test KIT).

IgM adalah kelas imunoglobulin yang pertama dibentuk atas rangsangan antigen, tetapi respon IgM umumnya pendek yaitu hanya beberapa hari, kemudian menurun. Fenomena ini digunakan untuk menentukan apakah suatu infeksi yang diderita oleh seseorang akut atau tidak (Baratawidjaja dan Renggenis, 2010).

Dari teori diatas membuktikan bahwa Rapid Test IgM Salmonella dapat mendeteksi adanya IgM Salmonella Typhi dalam serum manusia pada waktu 4-5 hari setelah terjadinya demam. Hasil pemeriksaan IgM Salmonella Rapid Test Positif menunjukan bahwa adanya infeksi sistemik akut pada manusia yang disebabkan oleh bakteri Salmonella typhi. Bakteri Salmonella typhi masuk kedalam tubuh manusia melalui makanan danminuman yang tercemar. Sebagian kuman dimusnahkan oleh asam lambung, sebagian lagi lolos dan masuk kedalam usus selanjutnya berkembang biak. Bila respon imunitas humoral mukosa (IgA) usus kurang baik maka kuman akan menembus sel-sel epitel (terutama sel-M) dan selanjutnya ke laminan propia. Dilaminan propia kuman berkembang biak dan difagosit oleh sel-sel fagosit terutama makrofag. Kuman dapat hidup dan berkembang biak didalam makrofag dan selanjutnya dibawa ke plak payeri ileum distal kemudian ke kelenjar getah bening mesenterika. Selanjutnya melalui duktus torasikus kuman yang terdapat dalam makrofag ini masuk kedalam sirkulasi darah (mengakibatkan bakterimia pertama yang asimtomatik), sehingga pada pemeriksaan IgM Salmonella Rapid Test didapatkan hasil IgM positif. Sedangkan untuk hasil Pemeriksaan IgM Salmonella Rapid Test yang negatif menunjukan bahwa bakteri Salmonella Typhi belum masuk dan berkembang biak kedalam aliran darah. Kemudian, hasil pemeriksaan IgM Salmonella Rapid Test yang negatif juga disebabkan karena pengambilan sampel tersebut masih pada tahap awal atau hari pertama pasien demam dan dapat juga disebabkan karena pasien tidak menderita demam typhoid tetapi menderita penyakit lain yang pada pemeriksaan fisik dan gejala klinis sama dengan demam typhoid.

Hasil Pemeriksaan kadar SGOT menunjukan bahwa dari 33 sampel suspek demam typhoid, 22 sampel diantaranya mengalami peningkatan kadar SGOT, sedangkan 11 sampel suspek demam typhoid lainnya tidak mengalami peningkatan kadar SGOT.

Pemeriksaan yang dapat dilakukan pada penderita demam typhoid adalah pemeriksaan fungsi hati(liver function 
test/LFT). Uji kimia klinik darah termasuk dalam pemeriksaan rutin untuk kasus demam typhoid. Beberapa uji kimia klinik yang dapat digunakan meliputi test SGOTdan SGPT. SGOT/SGPT seringkali meningkat, tetapi akan kembali normal setelah sembuhnya demam (Widodo, 2009). Pembengkakan hati ringan sampai sedang dijumpai pada 50\% kasus demam typhoid dan lebih banyak disebabkan oleh S. Typhi dari pada S. Paratyphi. Untuk membedakan apakah pembengkakan hati yang terjadi karena tifoid, virus, malaria atau amuba maka perlu diperhatikan kelainan fisik, parameter laboratorium, dan bila perlu histopatologik hati (Sudoyo, et al, 2009). Dari teori diatas dapat membuktikan bahwa pada penderita demam typhoid dapat terjadi peningkatan kadar SGOT. Peningkatan kadar SGOT disebabkan karena bakteri Salmonella Typhi masuk kedalam tubuh manusia dan telah menginfeksi organ-organ tubuh manusia (jantung, ginjal, hepar dan ileum). Selain itu faktor lain yang dapat mempengaruhi peningkatan kadar SGOT pada penderita demam typhoid adalah adanya penyakit lain seperti: pankreatitis akut, infark miokardium, kerusakan hepatoselular akut, syok, gagal jantung, sirosis infark paru.

Dari hasil pengujian hipotesis korelasi hasil pemeriksaan IgM Salmonella Rapid Test dengan kadar SGOT, dengan menggunakan uji statistik koefisien biserial didapatkan nilai $(\mathrm{r}=0.201)$, hal ini menunjukan bahwa terdapat korelasi positif atau searah dengan tingkat korelasi rendah.

Menurut penelitian yang dilakukan oleh Pohan HT (2004) dengan judul Maninfestasi Klinis dan Laboratorium Demam Typhoid di RS Persahabatan Jakarta. Dari hasil penelitian tersebut menyatakan bahwa pada penderita tersangka demam typhoid dapat terjadi peningkatan kadar SGOTdan kadar SGPT. Peningkatan kadar SGOT dan SGPT dapat menyebabkan terjadinya komplikasi pada hati misalkan hepatitis typhoid. SGOT dan SGPT seringkali meningkat tetapi kembali normal setelah sembuhnya demam typhoid. Karena kadar SGOT dapat meningkat pada penderita demam typhoid, maka teori tersebut dapat dibuktikan dari hasil penelitian mengenai korelasi hasil pemeriksaan IgM Salmonella Rapid Test dengan Kadar SGOT pada pasien Suspek Demam Typhoid di Rumah Sakit Baptis Kediri. Dari hasil penelitian korelasi hasil pemeriksaan IgM Salmonella Rapid Test dengan kadar SGOT pada pasien suspek demam typhoid di rumah sakit Baptis Kediri dapat disimpulkan bahwa $\mathrm{H}_{1}$ diterima yang menunjukan ada korelasi hasil pemeriksaan IgM Salmonella Rapid Test dengan Kadar SGOT pada pasien Suspek Demam Typhoid di Rumah Sakit Baptis Kediri.

\section{KESIMPULAN}

Dari hasil penelitian dan pembahasan korelasi hasil pemeriksaan $\operatorname{IgM}$ Salmonella Rapid Test dengan kadar SGOT pada pasien suspek demam typhoid di Rumah Sakit Baptis Kediri yang dilakukan tanggal 11 Mei-11 Juni 2015 dan berdasarkan hasil uji statistik menggunakan uji koefisien Biserial maka diperoleh nilai koefisien korelasi dari hasil pemeriksaan IgM Salmonella Rapid Test dengan kadar SGOT ( $\mathrm{r}=$ 0.201), hal ini menunjukan bahwa terdapat korelasi positif atau searah dengan tingkat korelasi rendah, yang artinya jika hasil pemeriksaan IgM Salmonella Rapid Test positif, akan diikuti dengan peningkatan kadar SGOT.

\section{SARAN}

1. Peneliti selanjutnya perlu bertemu langsung dengan pasien, sehingga peneliti dapat mengetahui diagnosis 
sampel (demam pasien pada hari keberapa, sudah mengonsumsi obatobatan atau belum).

2. Peneliti selanjutnya juga perlu memperhatikan IgG sebagai penanda adanya infeksi kronis yang disebabkan bakteri Salmonella typhi.

3. Perlu dilakukan penelitian lebih lanjut terhadap kadar SGPT sebagai penanda bahwa bakteri Salmonella telah menyebar ke organ retikuloendotelial terutama hati dan limpa.

\section{UCAPAN TERIMAKASIH}

Ucapan terimaksih ditujukan kepada Rumah Sakit Baptis Kediri sertas eluruh pihak yang telah membantu dalam penelitian ini.

\section{DAFTAR PUSTAKA}

Baratawidjaja, K. G., dan Rengganis, I. 2010. Imunologi Dasar, Edisi ke10. Jakarta: Universitas Indonesia.

DEPKES \& KESOS, WHO, UNEPA. 2012. Buku Pedoman Pelayanan Transfusi Darah, AABB Modul 1 tentang Sumbangan Darah Secara Aman. Jakarta: DEPKES \& KESOS, WHO, UNEPA..

Notoatmodjo, Soekidjo. 2012. Metodologi Penelitian Kesehatan. Jakarta: Rineka Cipta. Hal. 24.

Noor, N. N. 2006. Pengantar Epidemiologi Penyakit Menular. Jakarta: Rineka Cipta. Hal. 9-39.

Profil Data Kesehatan Indonesia Tahun 2011. 2012. Data telah dipublikasikan. Jakarta: Kementrian Kesehatan Republik Indonesia. Hal. 77.

Sudoyo, Aru. W., et al. 2009. Buku Ajar Ilmu Penyakit Dalam, Jilid III, Edisi ke-5. Jakarta Pusat: Interna Publishing.
World Health Organization(WHO) 2018.

Widodo, Djoko. 2009. Buku Ajar Ilmu Penyakit Dalam, Jilid III, Edisi ke-5. Jakarta Pusat: Interna Publishing. Hal. 2797-2800. 
Tabel 1. Hasil pemeriksaan IgM Salmonella Rapid test dengan kadar SGOT terhadap 33 sampel serum pasien suspek demam typhoid di Rumah Sakit Baptis Kediri

\begin{tabular}{|c|c|c|c|c|c|}
\hline \multirow[t]{2}{*}{$\mathrm{NO}$} & \multirow[t]{2}{*}{ Kode Sampel } & \multirow[t]{2}{*}{ Umur } & \multirow[t]{2}{*}{ Jenis Kelamin } & \multicolumn{2}{|c|}{ Hasil Pemeriksaan } \\
\hline & & & & $\begin{array}{c}\text { Rapid } \\
\text { Test }\end{array}$ & SGOT \\
\hline 1 & Sampel 1 & 45 tahun & Laki-laki & + & 136 \\
\hline 2 & Sampel 2 & 13 tahun & Laki-laki & + & 51 \\
\hline 3 & Sampel 3 & 21 tahun & Perempuan & + & 46 \\
\hline 4 & Sampel 4 & 27 tahun & Laki-laki & + & 66 \\
\hline 5 & Sampel 5 & 29 tahun & Perempuan & + & 97 \\
\hline 6 & Sampel 6 & 23 tahun & Perempuan & - & 50 \\
\hline 7 & Sampel 7 & 17 tahun & Laki-laki & - & 17 \\
\hline 8 & Sampel 8 & 18 tahun & Perempuan & + & 68 \\
\hline 9 & Sampel 9 & 50 tahun & Perempuan & + & 449 \\
\hline 10 & Sampel 10 & 37 tahun & Laki-laki & + & 668 \\
\hline 11 & Sampel 11 & 29 tahun & Laki-laki & + & 32 \\
\hline 12 & Sampel 12 & 15 tahun & Perempuan & + & 213 \\
\hline 13 & Sampel 13 & 15 tahun & Perempuan & - & 116 \\
\hline 14 & Sampel 14 & 5 tahun & Perempuan & + & 64 \\
\hline 15 & Sampel 15 & 39 tahun & Laki-laki & + & 46 \\
\hline 16 & Sampel 16 & 25 tahun & Laki-laki & + & 24 \\
\hline 17 & Sampel 17 & 26 tahun & Laki-laki & + & 52 \\
\hline 18 & Sampel 18 & 32 tahun & Laki-laki & + & 128 \\
\hline 19 & Sampel 19 & 26 tahun & Perempuan & + & 107 \\
\hline 20 & Sampel 20 & 8 tahun & Perempuan & + & 25 \\
\hline 21 & Sampel 21 & 29 tahun & Laki-laki & + & 50 \\
\hline 22 & Sampel 22 & 16 tahun & Laki-laki & + & 17 \\
\hline 23 & Sampel 23 & 25 tahun & Laki-laki & - & 33 \\
\hline 24 & Sampel 24 & 19 tahun & Perempuan & + & 111 \\
\hline 25 & Sampel 25 & 17 tahun & Laki-laki & + & 24 \\
\hline 26 & Sampel 26 & 5 tahun & Laki-laki & + & 30 \\
\hline 27 & Sampel 27 & 31 tahun & Laki-laki & + & 16 \\
\hline 28 & Sampel 28 & 10 tahun & Laki-laki & + & 24 \\
\hline 29 & Sampel 29 & 7 tahun & Perempuan & - & 52 \\
\hline 30 & Sampel 30 & 24 tahun & Perempuan & + & 128 \\
\hline 31 & Sampel 31 & 33 tahun & Perempuan & + & 302 \\
\hline 32 & Sampel 32 & 8 tahun & Perempuan & + & 25 \\
\hline 33 & Sampel 33 & 32 tahun & Perempuan & + & 125 \\
\hline
\end{tabular}

(Sumber: Data Primer Juni 2015)

Tabel 2. Karakteristik Subjek Penelitian

\begin{tabular}{cccccc}
\hline & $\mathrm{N}$ & Range & Minimum & Maximum & Mean \\
\hline $\begin{array}{c}\text { Umur } \\
\text { Valid N }\end{array}$ & 33 & 45.00 & 5.00 & 50.00 & 22.9091 \\
(listwise) & 33 & & & & \\
\hline
\end{tabular}

(Sumber: Data Primer Juni 2015) 
Tabel 3. Karakteristik Subjek Penelitian Berdasarkan Jenis Kelamin

\begin{tabular}{cccc}
\hline NO & Responden & Frekuensi & Persentase $(\%)$ \\
\hline 1 & Laki-laki & 17 & 52 \\
\hline 2 & Perempuan & 16 & 48 \\
\hline & Jumlah & 33 & 100
\end{tabular}

(sumber: Data Primer Juni 2015)

Tabel 4. Hasil Pemeriksaan Rapid Test

\begin{tabular}{cccc}
\hline No & Sampel & Frekuensi & Persentase (\%) \\
\hline 1 & Positif & 28 & 87 \\
\hline 2 & Negatif & 5 & 13 \\
\hline & Jumlah & 33 & 100 \\
\hline
\end{tabular}

(sumber: Data Primer Juni 2015)

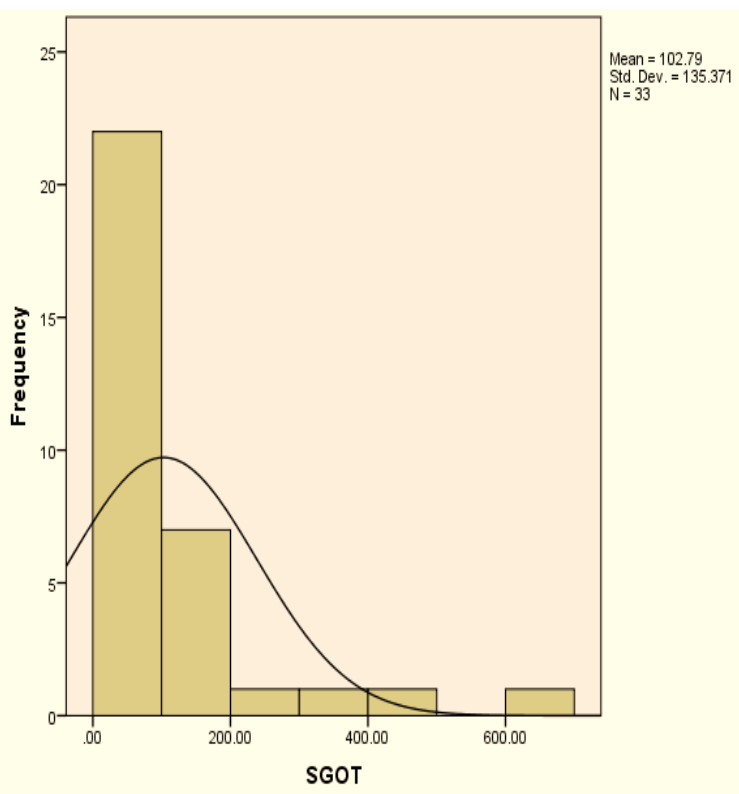

Gambar1. Histogram kadar SGO 